УДК: 811.163.41’342.8(497.11 Београд) DOI: https://doi.org/10.18485/belic_slv.2018.3.ch5

Владо Ђукановић

\title{
„БЕОГРАДСКИ СТИЛ” - ПРЕЛОМНИ ПЕРИОД У РАЗВОЈУ СРПСКОГ СТАНДАРДНОГ ЈЕЗИКА
}

„Београдски стил” представља период, а не тренутак у развоју српског стандардног језика. У том преломном периоду стандарднојезички модел коначно је престао да бива зависан од супстрата и постао је аутономна, функционално поливалентна и препознатљиво стабилна језичка формација, чије ће касније постепено и непотпуно кодификовање фиксирати српски стандардни језик у његовом савременом, актуелном облику.

Српски језички стандард почео се стварати крајем 18. и почетком 19. века по двема, данас се испоставља конвергентним линијама. Једна линија била је одређена наслеђеним језиком културе и покушајима његове модификације у смислу понарођавања, друга идиолектом и оквирима спознаје једног човека, које је он сажео у идеју „наш је народни језик и српски језик све једно, јер српскијех језика нема више до само један, којијем говори народ српски". У овој Вуковој идеји из средине 19. века данас можемо разабрати схватање супротстављености „народног језика” (као симбола чистоте језика, који има упориште у „народу”) и „језика књиге" (као симбола поглавито писаног језика натруњеног бројним „ненародним” обележјима, који нема упориште у „народу”). Расправе су, као што је познато, полазиле од претпоставке дивергентног развоја језика, али како се ближила средина века, постајало је јасно да опоненти ипак савршено разумеју једни друге, односно да расправе воде на $u c$ том језику. Језик у тим расправама већ је недвосмислено био „народни” у основи. Површинска разлика у графијском систему као и различите усмерености неких цивилизацијских лексичких слојева не могу, из данашње перспективе, ослабити такву процену. Суштина спора није лежала у

1 ППА 1845: 93. 
поларизацији „народни”/„ненародни” језик, него у двема концепцијама развоја „опћене правилности” језика.

Прва концепција, континуант славеносрпског, претпостављала је заснивање и уопштавање стандардног језика на народној основи с уважавањем постојећег графијског система те с уважавањем писаног језика који већ функционише као културни језик (у коме су нарочито лексички, а отуда и творбени и морфолошки ниво, носили одређен баласт писане традиције и славеносрпских језичких утицаја). Друга концепција, вуковска, такође је претпостављала народни језик у основи, али је нудила ослобађање од поменутог баласта те заснивање и уопштавање стандардног језика у облику апсолутно „народног” језика с модификованим, упрошћеним графијским системом.

Вуковски модел је, у погодним социјалним околностима, природно превладао, али су се пред њим, такође природно, поставили сви они проблеми који се постављају пред моделе који треба да се уопште, тј. који треба да преузму све функције стандардног језика одређене друштвене и државне заједнице.

Питање стандарднојезичког модела српског језика у тренутку када се поставља има јасну социјалну димензију. Српска државна матица тек се ствара из једне социјално хомогене, нераслојене народне заједнице, а културна матица је ван државних граница, у Војводини. Ова је социолошка чињеница веома битна када се говори о формирању стандардног језика и о селекцији идиома на коме ће стандард почивати. Као прво, тадашњи културни језик није довољно стабилизован да би могао надвладати вернакулар као природан избор друштвене заједнице којој тек предстоји социјално раслојавање. Као друго, једно од битних обележја стандардног језика јесте његов социјални престиж. У нераслојеној друштвеној заједници, каква је српска у матици средином 19. века, нема критичне масе носилаца престижа тадашњег културног језика, а стварни и потенцијални носиоци његовог престижа долазе са стране. ${ }^{2}$ Отуда је избор вуковског модела био спонтан и неминован. У држави која настаје, у којој тек почиње социјално раслојавање, у којој тек започиње формирање практично свих сегмената друштвеног живота, вуковски модел омогућавао је много бржи приступ писмености неупоредиво већем броју чланова заједнице него понарођени славеносрпски модел, који је, у неку руку, елитистички модел ограниченог социјалног домета.

Спонтано и постепено прихватање (или ширење) вуковског модела у четвртој и петој деценији 19. века, као и спонтано и постепено пона-

2 Уп. Луковић 1994: 33-36. 
рођавање континуанта славеносрпског модела, тек наговештавају стандардни језик. О стандардном језику може се говорити тек од времена свеобухватне акцепције ${ }^{3}$ једног модела, а до ње долази након званичног прихватања Вуковог графијског система, средином седме деценије 19. века. Погледајмо шта су битни фактори акцепције.

Милорад Радовановић с разлогом методолошки разлучује поступке службеног и стварног прихватања одређене норме ${ }^{4}$, али је, из перспективе стандардног језика, веома важно да акцепција буде свеобухватна, ${ }^{5}$ да се успоставе званични механизми који ће акцепцију норме подржавати и промовисати, ${ }^{6}$ као и да се сама норма у што већој мери стабилизује, што се све дешава у последње три деценије 19. века. С друге стране, у нашем случају, фазе акцепције и имплементације (која води успостављању функционалне поливалентности стандардног језика), те фазе експанзије и култивације норме (које воде утврђивању функционалне поливалентности стандардног језика), те фазе експанзије и култивације норме (које воде утврђивању функционалне поливалентности стандардног језика) суштински се прожимају, управо зато што нема кодификације. Да би се један моделирани идиом препознао као стандардни језик, нужно је, такође, да постане аутономан вид језика, што независнији од супстрата, да добије кодификацијске приручнике који ће оверавати ту његову аутономност и одржавати достигнути степен стабилности норме, те да стекне социјални престиж.

Избором вуковског модела није аутоматски сужена и основица стандардног језика на ону коју је предлагао Вук. Основица је, фактички, проширена на два новоштокавска дијалекта. ${ }^{7}$ Другим речима, процес селекције у случају српског стандардног језика подразумевао је два разлучива потпроцеса: 1) фазу селекције модела стандардног језика, и 2) фазу селекције типа језичке варијације који ће се уопштавати. До средине 19. века тадашњи културни језик већ се у доброј мери приближио

3 Фазе у стварању стандардног језика најпотпуније је код нас пописао Милорад Радовановић (1986).

4 Радовановић 1986: 194.

5 На ово још од Хавранека упозоравају чешки лингвисти. „Тако су нпр. језичку норму коју је за српскохрватски језик понудио Вук у пракси примењивали многи (међу ғима и писии), али је тек 1868. године [...] Вукова језичка норма званично прихваћена у тадашњој Србији” (Радовановић 1986: 194; истакао В. Ђ.). Вуков модел је у Србији стварно прихваћен, али не и свеобухватно прихваћен. Свеобухватност следи за званичним прихватањем његовог модела.

6 УП. Бугарски 1986: 217.

7 В. Ивић 1985: 69-70. 
свом супстратном шумадијско-војвођанском дијалекту (тј. битно га је апсорбовао) и та је чињеница суштински омела формирање норме искључиво на супстрату источнохерцеговачког дијалекта. С друге стране, стратешка блискост ${ }^{8}$ говора који чине полицентричну основицу нашег стандардног језика погодовала је успостављању имплицитне норме која је проистицала из узуса. ${ }^{9}$ Та је имплицитна норма током друге половине 19. века постепено и делимично елаборирана, експлицирана. ${ }^{10}$ Елаборација норме је једно време давала предност источнохерцеговачком супстрату (тзв. филолошка школа), али је узус успостављао равнотежу, с обзиром на то да су се главна културна средишта и жаришта, Београд и Нови Сад, налазила ван домашаја тог супстрата.

Тако је, рецимо, лексичка норма у Вуковом речнику из 1852. године добила облик који је у већој мери уважавао територијалну раслојеност српског језика. Уз њу, овај речник је представљао образац ортографске, ортоепске, те творбене и морфолошке норме. Научну, дескриптивну обраду ортоепске, творбене, морфолошке и делимично синтактичке проблематике у годинама након појаве речника из 1852. даје углавном Ђуро Даничић, на трагу Вуковог модела, али знатно шире од њега. Кодификације заправо нема, норма се прихвата подражавањем практичних модела, подражавањем готових образаца. ${ }^{11}$ Тек 1894 . године појављује се прва потпуна српска граматика, Сриска граматика Стојана Новаковића, која скупа с маретићевом Граматиком и стилистиком хрватскога или ср-

${ }^{8}$ Идеју о стратешкој блискости шумадијско-војвођанских и источнохерцеговачких говора можда је најбоље формулисао Далибор Брозовић говорећи о „стандардној новоштокавштини”. Чињеница је да се до данас нико није озбиљно позабавио питањем компарације битних особина ШВ/ИХ говора, односно комплексом који сачињава структуру српског стандардног језика и доприносима томе комплексу говора који му леже у основици.

9 "Standardisation is an intrinsic feature of the use of language; and whenever we set out to describe 'a language', i. e. to describe the ulterances that are or may be heard in a community as 'uses of a language', we are seeking to extract its standards" (Xac 1982: 15). Управо због тога, као и због појмовне оптерећености термина норма, има смисла инсистирати на томе да се разлучују имплицитно и експлицитно испољена норма (Ицкович 1970: 13), односно формализована и неформализована, прескриптивна и дескриптивна норма, како ове појаве називају различити аутори (уп. Барнет 1976: 65).

10 О томе детаљно в. код Ирене Грицкат (1988).

11 „Имплицитно норма выступает в виде образца, или, точнее, текстов, считаемых образцовыми ... В этой своей ипостаси норма проявляется в неявной, несформулированной, неописанной форме, представляет собой, так сказать, вещ в себе" (Ицкович 1970: 13). 
пскога језика. Међутим, експликација норме у обе ове граматике се, још увек, ослања на вуковски источнохерцеговачки образац за моделирање језика и често се позива на њега. ${ }^{12}$ Ипак, Новаковићева граматика је, уз методолошки и педагошки савременије школске граматике Љубомира Стојановића, ${ }^{13}$ у погодним социјалним околностима, отворила могућност убрзаније и доследније акцепције тако експлициране норме.

Ни „народни језик” ни „језик књиге” нису поседовали средином 19. века инструментаријум кодификоване норме. Тачније, „народни језик” има дескриптивне приручнике, Вукове речнике и граматику из 1818. године те Даничићеву Малу сриску граматику ${ }^{14}$, који су по природи ствари и нормативни приручници. С друге стране, прекасно, 1852. године појављују се Српски правопис Друштва српске словесности, односно Нинковићева, па Вујићева граматика, као приручници који би требало да репрезентују норму тадашњег културног језика. Међутим, ниједан од ових приручника не би се могао сматрати носиоцем кодификоване норме, јер су експликација норме (њена фиксација, фиксирање норме) и кодификација норме две фазе сложеног процеса. Наиме, експлицирана норма тек је „предлог за размишљање”, док је кодификована норма октроисана, подржана одређеним социјалним инструментима који је намећу. Другим речима, експлицирана норма може, али не мора бити кодификована. У држави која се ствара не постоје никакви механизми којима би се спроводило оно што бисмо данас назвали језичким планирањем/ нормирањем. Постојали су само стихијно супротстављени модели за заснивање и уопштавање стандардног језика. Међутим, у Србији која 1836. године има 72 основне школе (трогодишње и четворогодишње) и у њима

12 Маретићева у одређеном смислу стоји лошије од Новаковићеве. Као грађа за њу послужила су само Вукова и Даничићева дела, те оно што је Далибор Брозовић назвао „новоштокавском фолклорном коине”.

13 В. Грицкат 1988: 321. Стојановићеве граматике биле су у употреби још и у тридесетим годинама 20. века.

14 Уп. и нешто шири списак који даје Фекете (1984: 88): „Од језичког и књижевног арсенала, за даље развијање и усавршавање књижевнојезичког стандарда, писци пред којима је тај посао стајао имали су: а) дела Вука Караџића и народне умотворине - али као пример ијекавске српскохрватске језичке верзије, б) поетска остварења Бранка Радичевића и П. П. Његоша, в) Даничићеву Малу српску граматику [...] која је надопунила и својом систематичношћу надмашила Вукову, г) ново издање Вуковог Рјечника из 1852. године, много обимније од првог и употпуњено лексиком из разних крајева [...] са сређеном четвороакценатском прозодијском обележеношћу [...] и с назнаком екавске (па и икавске) варијанте одговарајућих лексема”. 
2514 ђака, а 1862. године 301 основну школу са 10725 ученика, ${ }^{15}$ односно у периоду (1840-1860) у коме се у просеку годишње штампа шездесетак српских књига, ${ }^{16}$ односно у Србији у којој 1864 . године има тек $4,7 \%$ писмених људи, ефекти нормирања језика не могу се ни очекивати.

Следећи важан елеменат распознавања стандардног језика јесте његова аутономност у односу на друге идиоме. Трагове теоријске свести о аутономности стандардног језика срећемо и код Стојана Новаковића: „Превод 'Новог Завјета' од Вука Ст. Караџића ... и превод 'Приповедака из Старога и Новога Завета' [...] Ђ. Даничића изнели су огледе тога језика, који је нашим филолозима лебдео пред очима као идеал чистога народног, или народнога књижевног језика, а који се - упамтимо добро - усвима појединостима, онакав какав је, нигде не говори у народу, макар да опет у нему нема ниједне појединости која се негде у народу не би говорила. Тиме су и Срби дошли до живота народног књижевног језика, који је управо рећи једино потпуно доследном правилношћу различит од народнога говорног језика"17 Кажем „трагови”, јер Новаковић говори о „народном књижевном језику” као о апстракцији, из чега, упркос контрадикцији у појмовима, произлази и идеја о његовој аутономности, али практичне аутономности нема у нешто каснијој реализацији Новаковићеве граматике. Тек Белић указује на аутономност као битан елеменат поимања стандардног језика. ${ }^{18}$

На морфолошком нивоу норма је аутономна скоро од Вука и има строже оквире, уз местимичну варијацију условљену супстратом, која се углавном нивелише почетком 20. века (уп. нпр. жутим $[\leftarrow$ жутим/жу-

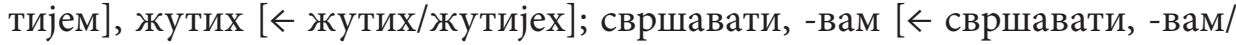
свршивати, -шујем] људима, зубима $[\leftarrow-$ ма/-има]; настојати $[\leftarrow$ настојати/настојавати]). Творбена норма подложна је нешто слободнијој варијацији него морфолошка, али у оквирима задатог и тешко променљивог скупа јединица, који је такође дефинисан у најранијим фазама експлицирања норме, при чему се варијација огледа у различитој дистрибуцији појединих афикса, тачније у промени фреквентности употребе појединих афикса.

„Београдски стил” је, међутим, одиграо кључну улогу у осамостављивању стандардног језика на лексичком и синтактичком нивоу и у усме-

\footnotetext{
15 Милићевић 1868: 7, 36.

16 Новаковић 1900: 36.

17 Новаковић 1888: 61-62.

18 „Када су се у Београду почела јављати поколења писаца чији је матерни језик био книжевни језик који се на показани начин стварао, онда је књижевни језик почео живети у делима њиховим - животом народног језика" (Белић 1934: 195).
} 
равању ова два нивоа стандарднојезичког модела ка њиховој савременој реализацији. Не само у језичком детаљу ${ }^{19}$ него много више у уочљивој тенденцији ка практичном остваривању богатије и кохерентније синтактичке и лексичке норме,$^{20}$ при чему под кохерентнијом нормом подразумевам виши степен синхроне инваријантности у њој. Када је реч о тенденцији у стандарднојезичком моделу, треба разликовати индивидуалне тенденције ка строжем граматичком систему од глобалних тенденција. Тако Станојчић, коментаришући два таква случаја у морфологији језика Лазе Лазаревића, уочава у њима индивидуалну тежњу ка хиперграматичности. ${ }^{21}$ У исти круг појава могли бисмо убројати, рецимо, и фреквентно вештачко замењивање инфинитива конструкцијом да+презент уз глаголе непотпуног значења у језику Милутина Ускоковића (уп. Ја мрзим зиму кад се мора да спава; Љутио се на дугме од кошуље, што се није могло да закачи; Публика се стане да намеће), ${ }^{22}$ али морамо бити свесни да Ускоковић истовремено прати и тенденцију у београдском узусу, без осећаја (и знања) да енклитика мора променити место када се инфинитив замени конструкцијом да+презент. На сличан начин, индивидуалне тенденције модификовања система можемо уочити код Милована Глишића; и мада су његове модификације дисперзиране и недоследне, у оквиру њих могу се издвојити оне које прате глобалне тенденције. ${ }^{23}$

Аутономност синтактичког нивоа, каква се развијала у оквирима „београдског стила”, показала се у низу процеса - редуковање система глаголских времена и ширење функција преосталих чланова система, неутрализовање и стабилизовање позиције атрибут + именица, неутрализовање алтернације адноминалних релативизатора који/щто, ${ }^{24}$ губљење глаголске енклитике у перфекту, неутрализовање позиције глагол непотпуног значеть + инфинитив, ширење процеса номинализације, преструктурирање сложених реченичких модела, ширење категорије тзв. реченичних прилога, који прецизирају семантички однос међу реченицама

19 Уп. измене које је Богдан Поповић унео у своју студију Бомарше у новијем издању из 1925. године (први пут објављена у Отацбини 1889. године): почем је он један од њених $\rightarrow$ пошто је он један од њених, ако има што нарочито да се савлада овде $\rightarrow$ ако има нешто нарочито да се савлада овде и сл.

20 В. Једличка 1974: 57-58.

21 Станојчић 1973.

22 За овај детаљ из Ускоковићевог језика захвалан сам колеги Мирославу Николићу који ми је љубазно уступио свој необјављени рад о језику Милутина Ускоковића.

23 В. Добрашиновић 1958: 176-187.

24 В. Станојчић 1967: 62-63 и 1987: 87-88. 
(међутим, напротив, итавище, наиме, додуще, ипак) и интерних реченичних модификатора (управо, сигурно, ујпште $)^{25}$ итд. Наше „нормативне” граматике, рецимо, и данас описују и прописују имперфект, али то не може поништити чињеницу да је имперфект с „београдским стилом”26 у стандардном језику дефинитивно прешао међу категорије које се и код натпросечно образованих корисника стандардног језика налазе у домену пасивног знања о језику, односно у неактуелизованој области реализоване норме. ${ }^{27}$ Овде се наравно ради о губљењу имперфекта из узуса, али не и из система. Постоје, такође, ситуације у којима има смисла говорити о стилогености имперфекта, тј. ситуације у којима је употреба/неупотреба имперфекта стилогена. ${ }^{28}$

С друге стране, лексички ниво је, у смислу избора лексема, веома подложан слободној варијацији и сам по себи врло флексибилан када га посматрамо у категоријама нормирања језика. „Београдски стил” је потпуно ослободио овај ниво од било каквог угледања на супстратне моделе и учинио га централним нивоом цивилизацијског надграђивања језика,

25 Уп. Брозовић/Ивић 1988: 39.

26 Биће и зато што га шумадијско-војвођански дијалекат, као његов супстратни идиом, не познаје, а упркос томе што је у источнохерцеговачком дијалекту он жив, иако не на читавој територији (уп. Ивић П. 1985: 74, 137).

27 УП. Скворцов (1970: 48): „Реализованная норма состоит из двух частей: 1) актуализованная часть (современная, активно действующая, осознаваемая и практически кодифицированная) и 2) неактуализированная часть (куда включается уходящие архаизмы, редко встречающиеся варианты, дублеты и т.п.).” Уп. такође Стевановић (1963: 86): „[...] и имперфекат, чије је губљење у живој народној речи ... већ раније узело најшире размере, ипак [се] чувао као особина књижевног језика".

28 В. нпр. оно што Добрашиновић (1958: 188) каже за Милована Глишића: „Глишићева проза има више динамике и краће мисаоне цјелине, има живљи ритам и богатији дијалог. Глишић, дакле, није епски широк, није разливен и тром као народни приповједач. Више воли краћу реченицу.” Нешто даље, на истој страници, о имперфекту код Глишића Добрашиновић вели: „Глишић се примјетно клони овог глаголског облика [имперфекта], који означавајући трајање радње изазива утисак развучености и спорости. Сем тога, разумије се, овдје треба узети у обзир и чињеницу да је имперфект у процесу губљења.” Другим речима, код Глишића се преклапају тенденција у узусу и стилски разлози. О функционализованости употребе имперфекта код Иве Андрића говори Станојчић (1987: 82-83): „Примери имперфекта у тим његовим ијекавским текстовима [у првим Андрићевим приповеткама] представљају уметничку транспозицију стања у локалном говору, транспозицију која је готово пишчев идиолект јер је заснована на јаком индивидуалном језичком осећању за н о р м у ранијих књижевнојезичких епоха, до краја XIX века.” 
што је у досадашњој литератури углавном препознавано, с разлогом, као „интелектуализација” језика.

„Београдски стил”, као почетна фаза савременог српског језичког стандарда, зачео се у урбаној генерацији која је у знатно већој мери него дотадашње походила школу, у генерацији интелектуалаца који су се у знатном броју школовали у иностранству и који су се у том смислу суштински одвојили од слабије артикулисане митологизоване апстракције Народа (коју је симболизовао неписмени сељак) и окренула се јаче артикулисаној, али такође митологизованој, апстракцији Нације (коју симболизује писмени грађанин). „Београдски стил” означава коначни раскид с подражавањем народског језика као суперпонираног стандарднојезичког модела и с њим Београд дефинитивно постаје српски стандарднојезички melting pot. „Београд је постао у току времена средиште у којем се скупља велики део оних који на нашој књизи раде. То јединство места и јединство живота учинило је да сви они који дуже времена у Београду станују, који се у њему рађају и у њему живе, радећи и на књижевности или науци његовој, - почињу да пишу или говоре, иако не потпуно истоветним, свакако врло уједначеним језиком. Тај језик интелектуалних кругова београдских и претставља београдски књижевни језик" (истакао В. Ђ.). ${ }^{29}$ Овај фактор „релативну повезаност књижевног језика с ограниченом групом, с ограниченим кругом носилаца", ${ }^{0}$ Једличка наводи као једно од пет диференцијалних обележја књижевног језика према другим језичким формацијама. Другим речима, формира се језичка индивидуалност града ${ }^{31}$ у коме су концентрисане и писменост, и наука, и култура, и државна администрација. Та језичка индивидуалност, с једне стране, помера глобалну стандарднојезичку оријентацију од неурбане ка урбаној, с друге стране, мења интенционалну доминанту стандарднојезичког модела у универзалистичку. ${ }^{32}$ Ово се дешава у последњој деценији 19. века и у прве две деценије 20. века. Непосредно пред I светски рат, а онда свом

29 Белић 1934: 193-194.

30 Једличка 1974: 45.

${ }^{31}$ Ивић М. 1990.

32 Уп. Барнетову (1976: 62) типологизацију стандардног језика: „Универсалистической тип в максимальной степени ориентирован на универсальные значимости, приспособления речевого поведения к ситуации. Превалирует направленность на функциональную адекватность сообщения соответствующей ситуации [...] Интенциональный тип ориентирован на достижение определенной цели, например, формирование нового литературного языка, приспособление его к новой коммуникативной ситуация, защита языка как символа национального самосознания и т. п.” 
силином након њега, полифункционални урбани стандард моделиран у Београду коначно постаје аутономан и утврђује се као престижни тип језичке варијације који усмерава матицу српског стандардног језика.

Као главни представници „београдског стила” досада су истицани Богдан и Павле Поповић, Слободан Јовановић, Јован Скерлић. Њиховим именима додао бих, за илустрацију, још неколико имена - Војислава Бекића ${ }^{33}$ (Сриско родољубље и отачаствољубље, 1910), Свет. Ж. Михаиловића (Основи железничарске тарифе, 1911), Николаја Велимировића (Религија Његомева, 1911), Ивана Ђаје (Ферменти и физиологија, 1912), Александра Белића (Срби и Бугари у балканском савезу и у међусобном рату, 1913). Ових неколико случајно изабраних наслова сугерише битно већу функционалну раслојеност оног стандарднојезичког модела који се идентификује као „београдски стил” него што је то до сада спомињано.

Такође битно обележје „београдског стила” јесте то што се он утврђује као суперпонирани писани образац стандарда. Вуковски модел настао је на усменим обрасцима и усмераван је тако да претпоставља усмену реализацију језика, па су чак и у развијенијим, каснијим варијететима овога модела, поткрај 19. века, неговани говорни обрти у писаној, књишкој реализацији. ${ }^{34}$ Идеја о значају писане реализације језика постојала је кроз читав 19. век, још од Вука. Отуда је у селекцији и акцепцији његовог модела стандардизације кључну улогу одиграла „ортографска" реформа, тачније реформа писма. Но тек у првим деценијама 20. века стекли су се друштвени услови за експанзију писаног стандарда, што је иначе један од првих услова за његову трајнију стабилизацију. У деценији пред I светски рат Србија има 1.425 основних школа са преко 140.000 ученика, ${ }^{35}$ убрзано се увећава број људи спремних да приме садржај књига и новина, па и језички, што веома погодује самоодржавању стандарда. Тако се у истом периоду ствара релевантан број емитената од-

33 Занимљиви су, у социолингвистичком контексту, подаци да је Бакић рођен у Топуском 1847. године, да је завршио реалну гимназију у Раковцу, учитељску школу у Сомбору, да је студирао педагогију и филозофију у Лајпцигу и Хајделбергу, а да је у Србију дошао 1875. године (према Станојевићевој Народној енциклопедији српско-хрватско-словеначкој).

34 Уп. нпр. Белић (1948: 227-228): „Тим се завршује прва епоха нашег књижевног језика и настаје нова када књижевници и писци (М. Ђ. Милићевић, Влад. Јовановић, Стојан Новаковић, Чедомиљ Мијатовић, Л. Лазаревић, Милован Глишић и др.) отпочињу писати својим књижевним језиком онако како се у њихову крају говори не водећи увек довољно рачуна ни о 'опћенитој правилности"”

35 ИСН 6/2: 533. 
говарајуће стандарднојезичког обрасца и битно проширује круг његових стварних и потенцијалних реципијената.

Отуда је период у коме се, на нивоу лексичке и синтактичке норме, мења глобална оријентација стандарда један од преломних периода у развоју нашег савременог стандардног језика. У том периоду престаје подражавање „вуковског стила” и почиње подражавање „београдског стила", што ће у коначном исходу, тридесетих година овога века, довести до стабилизовања синтактичке норме и до стварања темеља за савремену и потпуну кодификацију норме.

\section{ЛИТЕРАТУРА}

Барнет 1976: Барнет, „Языковая норма в социальной коммуникации”, Проблемы нормы в славянских литературных языках в синхронном и диахронном аспектах, Москва, 47-69.

Белић 1934: Александар Белић, „Београдски стил”, Нам језик 2/7, 193-200.

Белић 1948: Александар Белић, Вукова борба за народни и кюижевни језик, Београд.

Брозовић/Ивић 1988: Далибор Брозовић, Павле Ивић, „Језик, српскохрват-ски/хрватскосрпски, хрватски или српски", Извадак из II издаюа Енциклопедије Југославије, Загреб.

Бугарски 1986: Ранко Бугарски, Језику друштву, Београд.

Грицкат 1988: Ирена Грицкат, „Наука о српском језику код Срба у другој половини XIX века", Нам језик 27/5, 295-323.

Добрашиновић 1958: Голуб Добрашиновић, „О неким језичким и стилским појавама у приповијеткама Милована Ђ. Глишића”, Нам језик 9/5-6, 174-195.

Ивић П. 1983: Павле Ивић, „Језичке прилике”, Историја сриског народа, VI/2, Београд, 257-290.

Ивић П. 1985: Павле Ивић, Дијалектологија српскохрватског језика, Увод и штокавско наречје, Нови Сад.

Ивић М. 1990: Милка Ивић, О езику Вуковом и вуковском, Нови Сад.

ИСН I-VI: Историја сриског народа I-VI, Београд, 1981-1993.

Ицкович 1970: В. А. Ицкович, „Норма и ее кодификация”, Актуальные проблемы культуры речи, Москва, 9-39.

Једличка 1974: Alois Jedlika, Spisovnỳ jazyk v současné komunikaci, Praha. 
Луковић 1994: Милош Луковић, Развој српскога правног стила (Прилог историји језика и права у Србији), Београд.

Милићевић 1868: Милан Ђ. Милићевић, Школе у Србији од почетка овога века до краја школске 1867. године, Београд.

Новаковић 1888: Стојан Новаковић, Сриска књига, юени продавци и читаоци у ХІХ веку, Београд.

ППА 1845: Вука Стеф. Караџића и Саве Текелије писма ... Платону Атанацковићу ... о српскоме правопису, са особитијем додацима о српском језику, Беч.

Радовановић 1986: Милорад Радовановић, Социолингвистика, Нови Сад.

Скворцов 1970: Л. И. Скворцов, „Норма. Литературный язык”. Культура речи, актуалыные проблемы культуры речи, Москва, 40-103.

Станојчић 1967: Живојин Станојчић, Језик и стил Иве Андрића (функције синонимских односа), Београд.

Станојчић 1973: Живојин Станојчић, „Прилог тумачењу хиперграматичности", Јужнословенски филолог 30/1-2, 611-614.

Станојчић 1987: Живојин Станојчић, Граматика и језик, Титоград.

Стевановић 1963: Михаило Стевановић, „Синтаксичка синонимика”, Кюижевност и језик 10/2.

Фекете 1984: Егон Фекете, „Допринос српских писаца стварању књижевног језика у другој половини XIX века", Наш језик 26/2-2, 83-93.

Has 1982: W. Haas, On the normative character of language, Standard language (Spoken and written), ed. by W. Haas, Manchester University Press.

\author{
Vlado Đukanović \\ “BELGRADE STYLE” („BEOGRADSKI STIL”) - TURNING POINT IN DEVELOPMENT \\ OF SERBIAN STANDARD LANGUAGE
}

Summary

The period called "Belgrade style" is one of the turning points in the development of Serbian language and initial stage in the establishing of current standard language. That period extends over the first three decades of $20^{\text {th }}$ century. In that period syntactic and lexical norm became fixed, having reached a higher level of synchronic invariance than ever before. At the same time, growth of school system, spreading of literacy, social stratification, etc., created conditions 
for promoting, imitating and self-preservation of urban standard language that developed in the main administrative, cultural and scientific center - Belgrade. In the period called "Belgrade style" standard language definitely became idiom autonomous in relation to substratum dialects. 